\title{
KEPEMIMPINAN KEPALA MADRASAH DALAM MENANAMKAN KARAKTER RELIGIUS PESERTA DIDIK
}

\author{
Annisa Rohmawati \\ Universitas Islam Negeri Sunan Gunung Djati Bandung \\ annisarohmawati43@gmail.com \\ Supiana \\ Universitas Islam Negeri Sunan Gunung Djati Bandung \\ supiana@uinsgd.ac.id
}

\begin{abstract}
ABSTRAK
Karakter religius adalah karakter yang perlu dikuatkan salah satunya dengan cara penanaman karakter religius di madrasah. Terdapat fenomena yang menarik untuk diteliti yaitu Kepala MA Ar-Raudloh telah melaksanakan beberapa program penanaman karakter religius yang terbilang madrasah ini cukup muda yakni berdiri pada tahun 2014. Tujuan penelitian ini untuk mengetahui latar alamiah MA Ar-Raudloh, mengetahui gaya kepemimpinan Kepala MA ArRaudloh dalam menanamkan karakter religius peserta didik, mengetahui program penanaman karakter religius, serta mengetahui hasil dari program penanaman karakter religius. Metode yang digunakan dalam penelitian ini adalah metode deskriptif-kualitatif. Teknik pengumpulan data dilaksanakan dengan teknik wawancara, observasi, dan menyalin dokumen. Sedangkan dalam menganalisis data yang digunakan adalah analisis dengan penafsiran data. Uji absah data dilakukan dengan ketekunan pengamatan, triangulasi, pemeriksaan teman sejawat, analisis kasus negatif, kecukupan referensi, pengecekan anggota serta uraian rinci. Berdasarkan hasil penelitian, kepemimpinan Kepala MA ArRaudloh dalam menanamkan karakter religius sejalan dengan visi madrasah itu sendiri yaitu adanya program madrasah dalam meningkatkan karakter religius dan program keahlian seperti multimedia, tata busana dan usahawan. Kemudian rasa keterpanggilan dan keanggotaan dapat tercerminkan dari seluruh lapisan madrasah yang mengikuti pula program penanaman karakter layaknya peserta didik. Komitmen organisasi yaitu dapat menerima sanksi atas pelanggaran yang dilakukan baik itu oleh peserta didik maupun seluruh staf madrasah.
\end{abstract}

Kata kunci: kepemimpinan, karakter, religius

\section{ABSTRACT}

Religious character is a character that needs to be strengthened, one of which is by planting religious characters in madrasas. There is an interesting phenomenon to study, namely the Head of MA Ar-Raudloh has carried out several programs of inculcating religious character which is fairly young, namely this madrasa was 
founded in 2014. The purpose of this study was to determine the natural background of MA Ar-Raudloh, to know the leadership style of the Head of MA Ar-Raudloh. Raudloh in instilling the religious character of students, knowing the religious character planting program, and knowing the results of the religious character planting program. The method used in this research is descriptivequalitative method. Data collection techniques were carried out by interviewing, observing, and copying documents. Meanwhile, in analyzing the data used is analysis with data interpretation. The data validity test was carried out by diligent observation, triangulation, peer examination, negative case analysis, adequacy of references, member checking and detailed descriptions. Based on the results of the study, the leadership of the Head of MA Ar-Raudloh in instilling religious character is in line with the vision of the madrasa itself, namely the existence of madrasa programs in improving religious character and expertise programs such as multimedia, fashion and business. Then the sense of calling and membership can be reflected from all layers of madrasas who also participate in character building programs like students. Organizational commitment is being able to receive sanctions for violations committed by both students and all madrasa staff.

Key words: leadership, character, religious

\section{PENDAHULUAN}

Pendidikan merupakan suatu tempat dimana seseorang mendapatkan hak dan kewajiban. Guru dengan murid memiliki hak dan kewajiban yang berbeda-beda yang tentunya disesuaikan dengan porsinya masing-masing. Perbedaan hak dan kewajiban ini menghasilkan suatu persamaan yakni persamaan parsepsi keinginan murid dan keinginan guru dalam proses pembelajaran.

Pendidikan merupakan usaha sadar dan terencana yang dilakukan seseorang dalam mengembangkan potensi dirinya agar bermanfaat bagi kepentingan hidupnya. Pendidikan juga merupakan salah satu faktor yang dapat mempengaruhi kelangsungan hidup suatu bangsa. Melalui pendidikan diharapkan mampu mencetak generasi penerus bangsa yang berkualitas dan dapat memberikan kontribusi yang positif bagi kehidupan bangsa (Safitri, 2015).

Pelaksanaan kultur sekolah yang menjadi sebuah marwah sekolah berawal dari perubahan karakter terhadap peserta didik. Pembiasaan karakter yang dilakukan peserta didik menjadi langkah awal dalam kultur sekolah. Kultur sekolah itu tetap konsisten dan tetap berjalan meski dalam prosesnya terjadi sedikit gesekan atau ketidaknyamanan. Baik bagi peserta didik, pendidik atau orang tua peserta didik (Safitri, 2015).

Kepemimpinan adalah proses mempengaruhi dalam menentukan tujuan organisasi, memotivasi perilaku pengikut untuk mencapai tujuan, mempengaruhi untuk memperbaiki kelompok dan budayanya. Kepemimpinan juga mempengaruhi pengorganisasian, aktivitas untuk mencapai sasaran, memelihara hubungan kerjasama dan perolehan dukungan serta kerjasama dari orang-orang di luar kelompok atau organisasi. Kepemimpinan kepala madrasah mempunyai arti penting dalam suatu madrasah karena dapat meningkatkan kualitas dan efektivitas madrasah. Hal tersebut dapat diwujudkan dengan sistem kepemimpinan yang menjadi interaksi individu dan kelompok (peserta didik, guru, 
kepala madrasah, orang tua, masyarakat, dan karyawan). Produk yang diharapkan dari sistem seperti itu adalah terjadinya sebuah budaya organisasi madrasah yang kuat dan menjadikan proses pendidikan berjalan efektif dan efisien.

Karakter kepemimpinan kepala madrasah dapat berubah-ubah sesuai dengan situasi dan kondisi yang diadaptasikan dengan jati diri seorang kepala madrasah itu sendiri. Permasalahan yang ada di madrasah serta solusi yang diambil dipengaruhi oleh karakter kepemimpinan kepala madarasah yang dijalankannya. Ada banyak gaya kepemimpinan yang bisa diaplikasikan dalam pengelolaan sebuah organisasi formal seperti halnya kepemimpinan kepala madrasah terutama kepemimpinan yang berbasis pada era desentralisasi pendidikan. Diantara gaya kepemimpinan itu antara lain adalah kepemimpinan transaksional, kepemimpinan transformasional, kepemimpinan visioner, dan kepemimpinan spiritual. Karakter kepemimpinan yang dilakukan merupakan pandangan dari bawahan dan peserta didik tehadap kepala madrasah. Karena kepala madrasah merupakan pucuk pimpinan dan kiblat dalam pembentukan karakter yang harus diteladani oleh seluruh lapisan yang berada di lingkungan madrasah (Fatoni, 2017).

Kepemimpinan transaksional dalam dunia pendidikan mendeskripsikan bahwa kepala madrasah mengandaikan adanya tawar menawar antara berbagai kepentingan individual dari guru dan staf sebagai imbalan atas kerjasama dalam agenda kepala madrasah. Kepala madrasah sebagai pimpinan akan terus mengupayakan perbaikan-perbaikan evaluasi program, jalinan komunikasi, koordinasi, strategi mengatur target khusus dan kegiatan tugas-tugas untuk pemecahan masalah (Fatoni, 2017).

Kepemimpinan visioner merupakan kemampuan yang dilakukakan pemimpin dalam memberikan arahan akan visi yang realistik untuk masa depan dan sebelumnya telah dibuat beberapa perencanaan. Visi yang ditawarkan sebagian dari gambaran akan seperti apa madrasah terwujud yang tentunya disesuaikan dengan arus globalisasai dan tantangan yang harus dilewati. Kepemimpinan visioner memerlukan 4 kompetensi kunci, yaitu pertama harus memiliki kemampuan untuk berkomunikasi secara efektif dengan manajer dan karyawan lainnya dalam organisasi. Kedua, harus memahami lingkungan luar dan memiliki kemampuan bereaksi secara tepat atas segala ancaman dan peluang. Ketiga, harus memegang peran penting dalam membentuk dan mempengaruhi praktek organisasi, prosedur, produk dan jasa. Seorang pemimpin dalam hal ini harus terlibat dalam organisasi untuk menghasilkan dan mempertahankan kesempurnaan pelayanan, sejalan dengan mempersiapkan dan memandu jalan organisasi ke masa depan. Dan keempat adalah harus memiliki atau mengembangkan kemampuan untuk mengantisipasi masa depan (Sanusi \& Astuti, 2018).

Kepemimpinan spiritual merupakan kepimpinan kepala madrasah yang lebih menekankan pada aspek keduniawian yang di bawa kedalam aspek. keilahian. Kepemimpinan spiritual akan lebih terasa mudah dilakukan dibandingkan dengan gaya kepemimpinan yang lainnya, hal ini karena diri yang selalu mendekatkan kepada sang pencipta dan segala aspek sekecil apapun akan dikaitkan dengan Allah SWT. Gaya kepemimpinan ini banyak digunakan di madrasah karena latar belakang pendidikan yang kental akan kereligiusan. 
Teori spiritual leadership muncul beberapa tahun terakhir. Beberapa peneliti berusaha untuk menggali karakteristik spiritual leadership. Tingkah laku spiritual leadership termasuk menghormati orang lain, kesetaraan, kepedulian, identifikasi dengan kontribusi, reaksi untuk umpan balik dan refleksi diri (Reave, 2005). Hal tersebut dapat terjadi karena adanya faktor melayani. Melayani memiliki makna semangat batin untuk membantu orang lain, menjaga kepercayaan serta mampu menjadi pendengar yang baik (Dewantoro, 2017). Berikut ini merupakan gambar yang menunjukkan model dari spiritual leadership yang dikembangkan oleh Fry (2003)

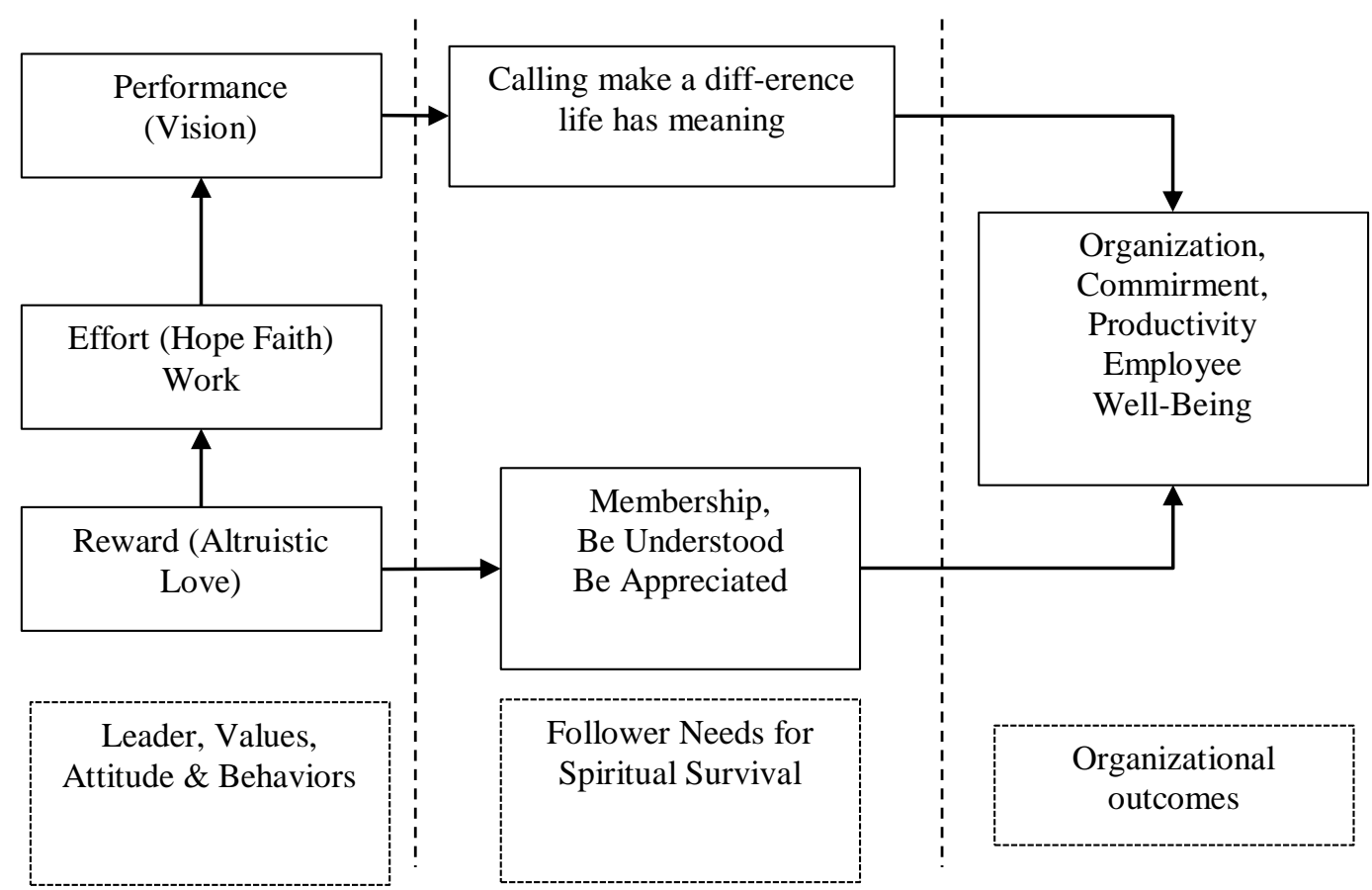

\section{Gambar 1. Model of Spiritual Leadership Theory}

Sumber: (Fry, 2003)

Pertama yaitu dimensi leader values, attitude and behaviors (nilai, sikap dan perilaku pemimpin). Values adalah sesuatu yang tertanam dalam diri seseorang bahkan sulit diubah untuk seseorang yang telah memasuki masa dewasa, lain halnya jika values itu tertanam pada anak kecil mungkin akan mudah untuk dirubah. Maka dalam masa-masa golden age, masa di mana anak sebagai peniru ulung karena yang mereka lihat dan dengar itu akan tertanam dalam dirinya dan segera dilakukan. Kehati-hatian orang tua dalam berkata dan bertindak dalam mendidik anak adalah kunci sukses menjadikan anak berkarakter baik.

Kedua yaitu dimensi spiritual survival, yang meliputi calling dan membership. Bagi sebuah lembaga pendidikan khususnya pemimpin, rasa terus hidup dalam memperjuangkan sesuatu yang telah dibangunnya adalah sebuah hal yang pasti tidak ingin berakhir. Banyaknya cerita bahkan jerih payah yang pemimpin lakukan harus tertanam pula dalam benak pemimpin-pemimpin selanjutnya. Begitupun mengenai spiritual survival pewarisan dari seorang pemimpin ke pemimpin selanjutnya harus terus terjaga agar keberlangsungan 
pendidikan tetap berjalan dengan baik tentunya akan selalu di ridhoi Allah SWT.

Ketiga yaitu dimensi organizational outcomes atau komitmen organisasi.

Komitmen menjadi salah satu hal yang terpenting dalam melakukan sesuatu. Dalam membangun madrasah tentunya komitmen harus dipegang teguh oleh seluruh staf pengajar. Komitmen disetujui atas dasar kesepakatan antara seluruh pihak yang bersangkutan, tidak bisa komitmen hanya dipegang oleh pemimpin saja atau bawahan saja. Komitmen menjadi sebuah janji yang harus dipegang demi tecapainya visi dan misi madrasah (Rahmawaty, 2016).

Secara umum, istilah karakter yang sering disamakan dengan istilah temperamen, tabiat, watak atau akhlak mengandung definisi pada sesuatu yang menekankan unsur psikososial yang dikaitkan dengan pendidikan dan konteks lingkungan. Dari sudut pandang behavioral yang menekankan unsur somatopsikis yang dimiliki sejak lahir, istilah karakter dianggap sebagai ciri atau karakteristik atau gaya atau sifat dari diri seseorang yang bersumber dari bentukan-bentukan yang diterima dari lingkungan (Siswanto, 2013).

Dunia pendidikan terdiri dari berbagai karakter, karakter peserta didik, tenaga pendidik dan tenaga kependidikan yang harus bisa dimengerti oleh kepala madrasah. Hal tersebut sebagai upaya dalam mensukseskan perbaikan madrasah, yang dimulai dari penanaman karakter kemudian berlanjut menuju pada pembinaan karakter. Terciptanya karakter yang satu tujuan dengan visi dan misi madrasah akan menghasilkan perubahan bagi madrasah tersebut.

Orang yang berkarakter merupakan sifat alami seseorang dalam merespon situasi secara bermoral, yang dimanifestasikan dalam tindakan nyata melalui tingkah laku yang baik, jujur, bertanggung jawab, menghormati orang lain, dan karakter mulia lainnya (Wardoyo, 2015). Karakter merupakan istilah yang berkaitan dengan psikologis atau ilmu kejiwaan karena berhubungan dengan kepribadian. Kepribadian seseorang berbeda antara satu dengan yang lainnya. Faktor yang melatarbelakangi hal tersebut adalah lingkungan keluarga, sekolah dan masyarakat. Kepribadian menjadi salah satu tolak ukur penilaian diri oleh orang lain karena menjadi sebuah ciri khas dari seseorang. Karakter mengandung unsur moral, sikap bahkan perilaku untuk menentukan seseorang memiliki akhlak atau budi pekerti yang baik. Karakter cenderung bersifat status, apalagi jika karakter tersebut didukung oleh lingkungan yang kurang baik maka semakin mendorong karakter itu pada kepribadian seseorang dan pengecapan orang lain terhadap individu itu kurang baik atau jelek.

Religius mempunyai makna keagamaan atau yang berkenaan dengan kepercayaan agama. Pendidikan religi memiliki konsep pendidikan bahwa suatu ajaran religi dijadikan sebagai sumber inspirasi untuk menyusun teori atau konsep-konsep pendidikan yang dapat dijadikan sebagai landasan untuk melaksanakan proses pendidikan. Ajaran religi yang berisikan kepercayaan dan nilai-nilai dalam kehidupan, dapat dijadikan sumber untuk menentukan tujuan pendidikan, materi pendidikan, metode, bahkan sampai pada jenis-jenis pendidikan (Huda, 2018).

Strategi yang dapat dilakukan diantaranya adalah keteladanan, pembelajaran, pemberdayaan dan pembudayaan, penguatan, dan penilaian adalah cara yang efektif dalam menganggulangi dan mengurangi berbagai masalah tersebut. Seperti kepala madrasah melakukan penanaman karakter melalui pembiasaan shalat dzuhur dan ashar berjamaah serta puasa senin dan 
kamis. Penanaman karakter tersebut butuh waktu yang lama karena harus mengubah karakter peserta didik yang tadinya buruk menjadi baik serta perlu adanya pengkajian mengenai latar belakang kepribadian peserta didik seperti kehidupannya di keluarga dan di masyarakat (Suryanti \& Widayanti, 2018).

Pendidikan karakter adalah usaha menanamkan kebiasaan-kebiasaan yang baik (habituation) sehingga siswa mampu bersikap dan bertindak berdasarkan nilai-nilai yang telah menjadi kepribadiannya. Dengan kata lain, pendidikan karakter yang baik harus melibatkan pengetahuan yang baik (moral knowing), perasaan yang baik atau loving good (moral feeling) dan perilaku yang baik (moral action) (Safitri, 2015).

Dalam rangka lebih memperkuat pelaksanaan pendidikan karakter telah teridentifikasi 18 nilai yang bersumber dari agama, Pancasila, budaya, dan tujuan pendidikan nasional, yaitu religius, jujur, toleransi, disiplin, kerja keras, kreatif, mandiri, demokratis, rasa ingin tahu, semangat kebangsaan, cinta tanah air, menghargai prestasi, bersahabat/komunikatif, cinta damai, gemar membaca, peduli lingkungan, peduli sosial dan tanggung jawab (Santoso, 2018).

Penanaman karakter religius dapat dikembangkan melalui tiga model pendidikan karakter yaitu: terintegrasi dalam mata pelajaran, pembudayaan sekolah, dan ekstrakurikuler. Penanaman karakter religius melalui integrasi dalam mata pelajaran, dalam konteks ini mata pelajaran yang memfokuskan untuk menanamkan karakter religius yaitu pada mata pelajaran Pendidikan Agama Islam. Namun demikian, dalam setiap mata pelajaran guru berhak menyisipkan pendidikan karakter pada peserta didik. Sehingga semua aspek saling mendukung dan memiliki tujuan yang sama (Wati \& Arif, 2017).

Setiap sekolah tentunya memiliki aturan-aturan tertentu salah satunya yaitu pembudayaan sekolah. Pembudayaan sekolah bisa dikatakan sebagai aturan yang harus dipatuhi oleh seluruh warga sekolah sehingga aturan tersebut lama-lama akan menjadi suatu kebiasaan baik yang tertanam pada diri seseorang. Kegiatan ekstrakurikuler merupakan salah satu kegiatan yang dilakukan untuk mengasah bakat yang dimiliki oleh seorang peserta didik. Salah satu ekstrakurikuler untuk mengasah bakat yang dimiliki peserta didik yaitu baca tulis Al-Quran (BTAQ). Selain fokus pada mengasah kempuan yang dimiliki oleh peserta didik guru ekstrakurikuler juga mananamkan nilai-nilai karakter pada setiap materi yang diberikan (Wati \& Arif, 2017).

Hasil dari wawancara pendahuluan yang peneliti lakukan terhadap kepala MA Ar-Raudloh diperoleh beberapa permasalahan diantaranya peserta didik yang berkata tidak sopan atau senonoh, kurang peka terhadap lingkungan, dan teman sebaya, rasa jujur dan disiplin yang masih kurang, serta masalah nilai-nilai religius seperti mengenyampingkan shalat di awal waktu dan kecintaan akan membaca AI-Quran yang perlu diselesaikan. Oleh karena itu peneliti tertarik untuk melakukan penelitian tentang bagaimana strategi kepala MA Ar-Raudloh dalam menanamkan karakter religious peserta didik.

\section{METODOLOGI}

Metode yang digunakan adalah metode deskriptif-kualitatif analitik. Teknik pengumpulan data dilakukan dengan teknik, observasi dan studi dokumentasi. Dalam teknik wawancara, peneliti terlebih dahulu menyiapkan pertanyaanpertanyaan yang akan dijadikan panduan dalam melakukan wawancara, namun 
tidak mengabaikan pertanyaan yang muncul seketika saat wawancara berlangsung. Observasi yakni aktivitas peneliti yang langsung turun ke lapangan untuk mengamati perilaku dan aktivitas individu-individu di lokasi penelitian. Objek yang diobservasi ialah kondisi lingkungan dan sumber daya MA ArRaudloh, mengamati proses kegiatan penanaman karakter dan mengamati proses evaluasi dari program tersebut. Dan menyalin dokumen yakni bertujuan untuk mendapatkan data-data tertulis yang dilakukan dengan cara penelusuran, dokumen, buku dan majalah yang berkaitan dengan penelitian.

Sedangkan dalam menganalisis data yang digunakan adalah analisis dengan penafsiran deskriftif. Teknik analisis data menggunakan unitisasi, kategorisasi data, dan penafsiran data. Adapun uji absah data yaitu perpanjangan keikutsertaan, ketekunan pengamatan, triangulasi, pemeriksaan teman sejawat, analisis kasus negatif, kecukupan referensi, pengecekan anggotauraian rinci, auditing untuk kriteria kebergantungan dan auditing untuk kriteria kepastian (Moleong, 2011).

\section{HASIL DAN PEMBAHASAN \\ Latar Alamiah MA Ar-Raudloh}

Madrasah Aliyah Ar-Raudloh berdiri dan beroperasi pada tahun 2014 yang berlokasi di Cileunyi, Kabupaten Bandung. MA Ar-Raudloh hadir sebagai solusi bagi dunia pendidikan untuk mencetak individu yang berkarakter, berilmu, agamis, berakhlakul karimah, mandiri, kreatif, dan inovatif. Dalam rangka pencapaian tujuan tersebut, MA Ar-Raudloh akan berkomitmen mengimplementasikan pendidikan berbasis pesantren dan mengembangkan pendidikan berorientasi kewirausahaan.

MA Ar-Raudloh hadir sebagai solusi pemerintah dalam pembangunan pendidikan juga membantu peserta didik yang tidak mampu namun tetap mengutamakan kualitas. MA Ar-Raudloh mengutamakan untuk memberikan pendidikan yang terjangkau, tidak ada diskriminasi, saling menghargai, kerja keras dan menguasai keterampilan hidup. MA Ar-Raudloh merupakan salah satu madrasah dengan bidang keahlian ilmu agama serta kewirausahaan. MA ArRaudloh hadir sebagai solusi atas kerinduan masyarakat terhadap pendidikan yang berkualitas namun terjangkau

\section{Kepemimpinan Kepala MA Ar-Raudloh}

Kepala madrasah adalah orang yang berpengaruh sekaligus jabatan tertinggi dalam lingkup madrasah. Pengelolaan madrasah yang baik terlihat dari peserta didik yang mematuhi aturan dan kesejahteraan guru yang terperhatikan. Ketika kedua hal tersebut dapat terlaksana dengan baik, salah satu tugas kepala madrasah dapat dikatakan sukses. Hasil akhirnya yaitu pengecapan mutu yang baik terhadap madrasah oleh masyarakat meski dalam prakteknya di zaman sekarang kategori mutu lembaga pendidikan yang baik adalah yang terlihat seperti sarana prasarana dan pendidiknya.

Gaya kepemimpinan kepala madrasah dapat terlihat dari beberapa program madrasah yaitu gaya kepemimpinan spiritual karena sejalan dengan visi dan misi madrasah. Selain sejalan dengan visi dan misi madrasah, ada hal penting dari kepemimpinan spiritual yang kepala madrasah lakukan yaitu 
menginginkan peserta didik dan seluruh staf madrasah lebih mengingat akhirat serta menambah rasa cintanya pada Allah SWT.

Kepemimpinan spiritual merupakan kepemimpinan yang berlandaskan dari etika religius dan selalu melibatkan Allah SWT dalam melakukan sesuatu. Hati dan pikiran selalu dikaitkan dalam menentukan suatu pilihan dan hasil akhirnya tidak akan pernah bertentangan dengan Al-Quran dan Hadits. Al-Quran dan Hadits menjadi rujukan dalam setiap tindakan, tidak hanya dunia yang dipikirkan melainkan juga akhirat. Kepala madrasah yang berjiwa religius akan mempertanggungjawabkan amanah dari bawahannya baik di dunia maupun di akhirat

\section{Program Penanaman Karakter Religius di MA Ar-Raudloh}

Dalam pelaksanaan penanaman karakter religius di MA Ar-Raudloh, tercermin dalam beberapa kegiatan, diantaranya adalah shalat Dhuha berjamaah, shalat Dzuhur berjamaah dan membaca Al-Quran, shalat Ashar berjamaah dan murjaah Al-Quran, puasa sunat Senin dan Kamis, mabit saat Ramadhan, bakti sosial, dan pesantren kilat.

Program penanaman karakter religius pertama yang dilakukan di MA ArRaudloh adalah shalat dhuha berjamaah. Shalat Dhuha ialah shalat yang dilakukan setelah matahari terbit dan dilaksanakan per dua rakaat, diantara shalat subuh dan shalat dzuhur. Banyak faedah yang dapat dirasakan setelah melaksanakan shalat duha diantaranya diperbanyak rizki dan dimudahkan dalam segala sesuatu. Selain shalat duha, diadakan kegiatan yang dapat memacu rasa kepercayaan diri peserta didik, yakni dilakukannya pemberian materi pembelajaran Bahasa Arab tepatnya materi mufrodat yang dilakukan peserta didik, tentunya peserta didik yang telah memahami betul materi tersebut. Hal demikian dapat mengasah kembali kemampuan peserta didik yang telah mahir sekaligus dapat membuat teman lainnya mengerti.

Program penanaman karakter religius kedua yang dilakukan di MA ArRaudloh adalah shalat dzuhur berjamaah dan membaca AI-Quran. Shalat lima waktu menjadi sebuah kewajiban bagi setiap muslim, salah satunya shalat dzuhur. Kepala MA Ar-Raudloh membuat program ini dengan tujuan agar peserta didik dan seluruh staf pengajar memiliki kebiasaan shalat berjamaah. Keutamaan shalat berjamaah selain pahala yang lebih besar, dapat mempererat rasa kebersamaan antara seluruh staf pengajar dan peserta didik.

Program penanaman karakter religius ketiga yang dilakukan di MA ArRaudloh adalah shalat ashar berjamaah dan murajaah Al-Quran. Program seperti ini tidak jauh berbeda dengan program-program sebelumnya yakni menciptakan peserta didik agar memiliki kebiasaan shalat berjamaah. Kemudian murajaah Al-Quran adalah kegiatan untuk membuat peserta didik mengingat kembali hafalannya, baik hafalannya yang dilakukan secara bersama atau hafalan yang dihafalkan sendiri.

Program penanaman karakter religius ketiga yang dilakukan di MA ArRaudloh adalah puasa sunat setiap hari Senin dan Kamis. Puasa adalah salah satu rukun Islam yang harus setiap muslim lakukan. Dalam program ini, puasa senin dan kamis menjadi salah satu program yang mewajibkan seluruh peserta didik dan staf pengajar berpuasa. Karena dengan mewajibkan yang sunah membuat peserta didik terbiasa melaksanakan perintah-perintah sunah Allah 
SWT.

Program penanaman karakter religius keempat yang dilakukan di MA ArRaudloh adalah mabit saat ramadhan. Mabit atau sering disebut sebagai malam pembinaan mental adalah program baru yang pertama dan terlaksana di tahun ini. Kegiatan mabit sama halnya dengan kegiatan yang dilaksanakan dalam kegiatan sekolah atau madrasah lainnya dan lebih tepatnya dilaksanakan ketika Masa Orientasi Peserta Didik Baru (MOPD), namun di MA Ar-Raudloh mabit ini dilaksanakan ketika memasuki bulan suci Ramadhan serta diikuti oleh kelas X, XI, dan XII tepatnya hari kedua di bulan Ramadhan.

Program penanaman karakter religius kelima yang dilakukan di MA ArRaudloh adalah baksos atau bakti sosial. Bakti sosial ialah program baru yang kedua dan pelaksanaannya ketika memasuki bulan suci Ramadhan. Kegiatan ini berbeda dengan kebanyakan bakti sosial lakukan seperti mengumpulkan baju bekas atau makanan pokok lalu memberikannya kepada yang membutuhkan melainkan pembersihan masjid. Membersihkan masjid secara bersama-sama secara tidak langsung akan menambah rasa cinta peserta didik untuk selalu merawat atau menjaga masjid. Pelaksanaan dari baksos ini yaitu satu minggu sebelum memasuki bulan suci Ramadhan. Persiapan yang matang menyambut bulan Ramadhan akan semakin giat dan membuat betah pula peserta didik dalam melaksanakan kegiatan yang dilakukan di dalam masjid. Seperti shalat berjamaah, murajaah Al-Quran atau itikaf yang dilaksanakan oleh santri yang mondok di pesantren Ar-Raudloh.

Program penanaman karakter religius keenam yang dilakukan di MA ArRaudloh adalah pesantren kilat. Pesantren kilat adalah program baru yang ketiga dan terlaksana di tahun 2019. Kegiatan ini dilaksanakan sekitar 4 hari terhitung dari tanggal 13 sampai dengan 16 Mei 2019. Hal ini bertujuan untuk mengisi awal bulan suci ramadhan dengan kegiatan yang baik, seperti pemberian motivasi atau ceramah dari pendidik akan keistimewaan dari bulan suci ramadhan.

Semua program tersebut diikuti oleh seluruh peserta didik mulai dari TK, SDIT, MTs, dan MA. Berhubung MA Ar-Raudloh ini merupakan yayasan yang didalamnya terdapat empat tingkatan jadi kegiatan ini dilaksanakan secara bersama-sama. Terkhusus bagi peserta didik MA diberikan mandat menjadi mentor atau pembimbing dalam kegiatan pesantren kilat untuk semua adik tingkatnya.

\section{Hasil dari Program Penanaman Karakter Religius di MA Ar-Raudloh}

Menurut salah satu peserta didik adanya shalat duha berjamaah dapat memberikan efek semangat dalam menjalani kegiatan pembelajaran. Selain hal tersebut dapat memberikan rasa percaya diri yang tinggi. Kemudian adanya mufrodat yang diselingi dengan permainan-permainan menambah rasa senang. Program tersebut dilaksanakan dari pukul 07:00 sampai dengan pukul 07:30 dengan durasi waktu 30 menit, yakni 15 menit untuk pelaksanaan shalat duha dan 15 menit untuk pembinaan akhlak oleh pendidik atau pemberian materi mufrodat oleh peserta didik. Salah satu cara untuk membuat peserta didik tersadar akan pentingnya berperilaku baik dan selalu mematuhi aturan yakni dengan adanya pembinaan akhlak yang berdurasi 15 menit yang dilakukan oleh pendidik. Dalam setiap pembahasannya tergantung pada hal yang sering ditemui. Salah satu isi ceramah pendidik mengenai berlaku sopan terhadap 
orang yang lebih tua dan selalu menjaga kebersihan lingkungan madrasah. Dari hal tersebut setidaknya dapat menggugah atau menjadi cambukan akan sikap buruk peserta didik. Selain dari pembinaan akhlak dilakukan pula pemberian materi mufrodat yang dilakukan peserta didik. Tujuan dari pembelajaran mufrodat ialah agar peserta didik mampu atau memiliki keahlian berbicara Bahasa Arab. Terkadang ada peserta didik yang paham struktur dari kalimat Bahasa Arab tetapi tidak dapat mengatakannya dengan benar. Adapula peserta didik yang mampu mengatakannya tetapi dalam strukturnya belum baik. Meskipun dalam prakteknya tidak sepenuhnya diserahkan pada peserta didik, melainkan pendidik pun memantau keberlangsungan jalannya penyampaian materi mufrodat.

Hasil dari program shalat dzuhur berjamaah dan membaca Al-Quran ialah salah satunya membuat peserta didik memiliki kebiasaan akan shalat berjamaah dan shalat di awal waktu. Dengan hal seperti ini tidak akan ada lagi alasan peserta didik untuk tidak melaksanakan shalat. Karena shalat lima waktu adalah shalat wajib dan tidak bisa untuk digantikan.

Persiapan pelakasanaan shalat dzuhur berjamaah sekitar 10 menit sebelum dikumandangkannya adzan dzuhur. Hal ini dilakukan agar peserta didik dapat mempersiapkan untuk pelaksanaan shalat seperti berwudhu. Peserta didik pun diberikan tugas sebagai muazin, jadi tidak ada muazin khusus. Hal yang demikian bertujuan sebagai wadah peserta didik mengolah kembali kemampuan suara adzannya agar semakin merdu. Setelah shalat dzuhur selesai, dilanjutkan dengan kegiatan membaca Al-Quran yang dibagi dalam beberapa kelompok dan setiap kelompok dipandu dengan satu orang guru. Tujuan dari kegiatan ini agar peserta didik memiliki kecintaan terhadap Al-Quran dan sedikit demi sedikit dapat menghafal Al-Quran. Selain kecintaan terhadap Al-Quran dapat pula menjadi kegiatan dalam mengolah diri agar semakin baik dalam membaca Al-Quran.

Hasil dari program program shalat ashar berjamaah sama halnya dengan program sebelumnya yakni menanamkan kebiasaan shalat di awal waktu dan selalu ingin melaksanakannya dengan berjamaah. Dalam program ini, diadakannya murajaah hafalan peserta didik dengan demikian proses penghafalan dapat dengan mudahnya terhafalkan.

Hasil dari program puasa Senin dan Kamis adalah program yang cukup memberatkan peserta didik karena harus melaksanakan yang sunah menjadi kewajiban, awalnya harus memaksakan diri akan tetapi setelah dicoba sangat menyenangkan. Terkadang keistiqomahannya yang kurang seluruh peserta didik terapkan. Manfaat yang dapat dirasakan bagi peserta didik ialah mampu mengelola diri agar senantiasa mengontrol emosi dan selalu berbuat baik. Diantaranya mengedapankan rasa jujur, disiplin, dan selalu peka terhadap teman sebaya yang mungkin memerlukan bantuan. Dalam kondisi seperti ini, seseorang akan takut ketika hendak melakukan hal yang buruk. Harapan dari program puasa Senin dan Kamis ini adalah agar peserta didik selalu merendahkan hati dan tidak bersikap berlebihan dalam segala hal, serta menanamkan pada peserta didik bahwa semua manusia itu derajatnya sama, dan yang membedakan hanya amal. Pelaksanaan program ini tidak dapat berjalan mulus, ada faktor penghambat yang ditimbulkan diantaranya kepala madrasah tidak dapat mengetahui satu per satu peserta didik apakah melaksanakan puasa Senin dan Kamis atau tidak. Karena puasa tidak dapat terlihat lain halnya dengan shalat berjamaah dan hal ini akan berkaitan dengan kejujuran. Dari faktor 
tersebut dapat pula melatih rasa kejujuran peserta didik, karena hal yang demikian berkaitaan dengan Allah SWT. Manusia dapat membohongi diri sendiri tapi tidak bisa untuk membohongi Allah SWT. Namun, pihak madrasah dapat mengurangi ketidakjujuran peserta didik dalam program ini yakni dengan tidak dibukanya kantin madrasah dan tidak diperbolehkan gerobak-gerobak pedagang berkeliaran di lingkungan madrasah. Dengan hal ini mau tidak mau peserta didik akan mengikuti program puasa senin dan kamis.

Mabit (malam pembinaan mental) ialah kegiatan untuk membina karakter peserta didik menjadi manusia yang selalu berperilaku baik. Kuat jiwa dan kuat mentalnya itu salah satu tujuan dari program tersebut. Pembinaan menjadi salah satu cara dalam penanaman karakter peserta didik karena dengan membina akan membantu peserta didik untuk lebih baik dalam berperilaku. Hasil dari kegiatan mabit tersebut ialah mempererat tali silaturahmi, pembinaan karakter pada peserta didik, dan mendekatkan diri kepada Allah SWT. Tali silaturahmi antar seluruh lapisan madrasah haruslah dijaga karena dari hal kecil ini dapat berdampak besar. Salah satu contohnya berdampak pada keikutsertaannya lapisan madrasah dalam menyukseskan seluruh program-program madrasah. Kebersamaan yang mungkin hanya didapatkan pada mabit ini dapat memperkuat kembali rasa kekeluargaan.

Program bakti sosial (baksos) ini memfokuskan peserta didik untuk memiliki rasa kepeduliaan dan mengajarkan gotong royong. Kepekaan terhadap lingkungan sekitar menjadi salah satu tujuan dari program ini. Bakti sosial yang diadakan hanya sekedar program yang melibatkan seluruh peserta didik dan mungkin kedepannya dapat berkontribusi dan bekerjasama dengan masyarakat luar yakni bakti sosial dengan skala yang lebih besar. Penanaman karakter dengan skala kecil seperti ini memang lebih mudah terkontrol oleh kepala madrasah, dapat dilihat peserta didik yang memiliki karakter mencintai keindahan dan mengedapankan kepentingan bersama dengan peserta didik yang tidak mau ikut campur (gotong royong) dalam bakti sosial.

Program pesantren kilat adalah salah satu program yang hanya diadakan ketika memasuki bulan suci Ramadhan. Program ini dapat menjadi salah satu cara penanaman karakter pada peserta didik, yakni karakter religius. Dengan diadakannya satu kali dalam setahun, peserta didik akan berlomba-lomba untuk mengikutinya baik itu ada permainan tentang pengetahuan agama Islam dan materi-materi yang berhubungan dengan bulan suci Ramadhan. Dengan hal ini dapat menjadi sebuah peluang bagi pihak madrasah mengolah kegiatan ini agar berjalan secara baik.

\section{SIMPULAN}

Program-program penanaman karakter religius di MA Ar-Raudloh dapat memperlihatkan gaya kepemimpinan kepala madrasah dengan tipe kepemimpinan spiritual yaitu menyeimbangkan antara keduniawian dengan keakhiratan. Diantara program yang cukup memberikan dampak besar pada pribadi peserta didik ialah program shalat berjamaah dan murajaah Al-Quran. Peserta didik akan menanamkan dalam dirinya kebiasaan shalat berjamaah di masjid yang setelah itu membaca Al-Quran. Serta program puasa Senin dan Kamis yang menanamkan pada peserta didik makna dari sebuah kejujuran meski 
dalam proses pengawasannya masih belum sempurna terhadap peserta didik yang bukan anak pondok.

\section{REFERENSI}

Dewantoro, A. (2017). Urgensi Spiritual Leadership Sebagai Upaya Meningkatkan Pelayanan Guru Bimbingan Konseling/Konselor Yang Profesional. Prosiding Seminar Bimbingan Dan Konseling, 1-8. http://pasca.um.ac.id/conferences/index.php/snbk/article/view/201

Fatoni, M. (2017). Peran Kepala Madrasah Dalam Meningkatkan Mutu Guru Di Mts Nurul Falah Talok Kresek Kabupaten Tangerang. Tarbawi: Jurnal Keilmuan Manajemen Pendidikan, 3(2), 168-182. https://doi.org/10.32678/tarbawi.v3i02.1787

Fry, L. W. (2003). Toward a Theory of Spiritual Leadership. The Leadership Quarterly2, 14(6), 693-727. https://doi.org/10.1016/j.leaqua.2003.09.001

Huda, M. B. (2018). Kontrol Nilai Religius dan Humanistis dalam Pendidikan Karakter. Widyabastra, 06(1), 84-89. http://ejournal.unipma.ac.id/index.php/widyabastra/article/view/3371

Moleong, L. J. (2011). Metodologi Penelitian Kualitatif. Remaja Rosda Karya.

Rahmawaty, A. (2016). Model Kepemimpinan Spiritual Dalam Meningkatkan Kepuasan Kerja Dan Kinerja Karyawan di BMT se-Kabupaten Pati. IQTISHADIA: Jurnal Kajian Ekonomi Dan Bisnis Islam, 9(2), 276. https://doi.org/10.21043/iqtishadia.v9i2.1732

Reave, L. (2005). Spiritual Values And Practices Related to Leadership Effectiveness. The Leadership Quarterly, 16(5), 655-687. https://doi.org/10.1016/j.leaqua.2005.07.003

Safitri, N. M. (2015). Implementasi Pendidikan Karakter Melalui Kultur Sekolah Di SMPN 14 Yogyakarta. Jurnal Pendidikan Karakter, 2, 173-183. https://doi.org/10.21831/jpk.v0i2.8621

Santoso, W. H. (2018). Kepemimpinan Transformasional Kepala Madrasah Dalam Membangun Karakter Siswa Di Mi Ma'arif Bego Depok Sleman. Nidhomul Haq: Jurnal Manajemen Pendidikan Islam, 3(2), 57-75. https://doi.org/10.31538/ndh.v3i2.76

Sanusi, H. P., \& Astuti, A. (2018). Model Kepemimpinan Kepala Madrasah. Jurnal Isema: Islamic Educational Management, 3(1). https://doi.org/10.15575/isema.v3i1.3288

Siswanto, S. (2013). Pendidikan Karakter Berbasis Nilai-Niali Religius. Tadris: Jurnal Pendidikan Islam, 8(1), 2-17. https://doi.org/10.19105/tjpi.v8i1.385

Suryanti, E. W., \& Widayanti, F. D. (2018). Penguatan Pendidikan Karakter Berbasis Religius. Conference on Innovation and Application of Science and Technology (CIASTECH 2018), 254-262. http://publishingwidyagama.ac.id/ejournal-v2/index.php/ciastech/article/view/630

Wardoyo, S. M. (2015). Pendidikan Karakter: Membangun Jatidiri Bangsa Menuju Generasi Emas 2045 Yang Religius. TADRIS: Jurnal Pendidikan Islam, 10(1), 90-103. https://doi.org/10.19105/jpi.v10i1.640

Wati, D. C., \& Arif, D. B. (2017). Penanaman Nilai-nilai Religius di Sekolah Dasar untuk Penguatan Jiwa Profetik Siswa. Prosiding Konferensi Nasional Kewarganegaraan III. http://eprints.uad.ac.id/9629/ 